\title{
Short communication: Effect of canola meal use as a protein source in a starter mixture on feeding behavior and performance of calves during the weaning transition
}

\author{
D. Hadam, ${ }^{*}$ J. Kański, ${ }^{*}$ K. Burakowska,† G. B. Penner,† Z. M. Kowalski, ${ }^{*}$ and P. Górka*1 \\ *Department of Animal Nutrition and Dietetics, University of Agriculture in Krakow, Al. Mickiewicza 24/28, 30-059 Krakow, Poland \\ †Department of Animal and Poultry Science, University of Saskatchewan, 51 Campus Drive, Saskatoon, SK, S7N 5A8, Canada
}

\begin{abstract}
The aim of this study was to determine the effect of canola meal use as a protein source in a starter mixture (SM) on feeding behavior and performance of calves during weaning transition. A total of 36 female Holstein calves of a mean age $14.9 \pm 1.6 \mathrm{~d}$ and body weight 40.1 $\pm 4.2 \mathrm{~kg}$ (mean $\pm \mathrm{SD}$ ) were allocated to 1 of 3 treatments differing in the main source of protein for the SM (12 calves per treatment): (1) soybean meal (TSBM); (2) soybean meal and canola meal (TSBM/TCM); and (3) canola meal (TCM). The SM was offered for ad libitum consumption beginning on the first day of the study, whereas milk replacer (MR) was fed in amounts equal to $900 \mathrm{~g}$ (as fed) per day from d 1 to 35 and 450 $\mathrm{g} / \mathrm{d}$ from d 36 to 42 of the study. Calves were completely weaned on d 43 of the study ( $57.9 \pm 1.6 \mathrm{~d}$ of age; mean $\pm \mathrm{SD}$ ), and their performance was monitored for an additional 2 wk. Calf body weight was recorded weekly, and MR and SM intake and fecal fluidity were recorded daily. Feeding behavior of calves during weaning transition, including frequency (no./d), time $(\mathrm{min} / \mathrm{d})$, and rate $(\mathrm{g} / \mathrm{min})$ of eating the SM as well as frequency and time of drinking water, was monitored on 6 calves per treatment for 2 consecutive days before MR step-down (d 34-35), at MR step-down (d 41-42), and after weaning (d 48-49 of study). Starter mixture intake tended to be higher for TSBM calves as compared with TSBM/ TCM calves from d 1 to 35 of the study but was not different between TSBM and TCM calves and was not different between treatments in the whole study period. Calves from TCM treatment had reduced average daily gain (ADG) and feed efficiency (g of ADG/kg of dry matter intake) and a higher fecal score in the period from d 1 to 35 of the study and had lower feed efficiency and tended to have lower ADG in the whole study period as compared with TSBM calves. Average
\end{abstract}

Received September 14, 2015.

Accepted October 19, 2015.

${ }^{1}$ Corresponding author: p.gorka@ur.krakow.pl daily gain and feed efficiency did not differ between TSBM and TSBM/TCM calves. Frequency of eating the SM and drinking water as well as time and rate of eating the SM and time of drinking water did not differ between treatments. It is concluded that presence of canola meal in a SM does not affect feeding behavior and performance of calves during weaning transition but has a negative effect on ADG, feed efficiency, and number of days with diarrhea during the preweaning phase of rearing.

Key words: rearing calves, starter diet, feed efficiency, weaning

\section{Short Communication}

Canola meal $(\mathbf{C M})$ is commonly discouraged as a protein source in starter mixtures $(\mathbf{S M})$ for calves. This is mainly a result of concerns with low palatability and digestibility of CM because of presence of unpalatable compounds (tannins, phenolic acids), antinutritional factors (erucic acid, glucosinolate, trypsin inhibitor, phytates), and relatively high fiber content in CM (Fiems et al., 1985; Khorasani et al., 1990). Even though these concerns were not confirmed in all studies (Fisher, 1980; Claypool et al., 1985), some showed lower feed intake and nutrient digestibility when CM was used as a protein source in calf starters (Fiems et al., 1985; Khorasani et al., 1990), at least when compared with soybean meal (SBM). However, the negative effect of $\mathrm{CM}$ on feed efficiency in calves may not only be a result of its chemical constituents, but also its effect on feeding behavior of calves. It has been shown, for example, that corn grain endosperm type and some feed additives used in diets for cattle affect feeding time, frequency, and rate (Lunn et al., 2005; Taylor and Allen, 2005; DeVries and Chevaux, 2014), which itself may affect the rumen environment and in consequence, feed efficiency (Allen, 1997). In reference to calf nutrition, the use of dried distillers grains with solubles in SM increased SM intake rate in the first weeks of life, which was associated with lower rumen $\mathrm{pH}$ (Laarman 
et al., 2012). The effect of SM composition on feeding behavior of calves, and in consequence efficiency of feed digestion and utilization, may be especially apparent during weaning transition, a period when SM intake increases rapidly (Quigley et al., 2006; Laarman et al., 2012).

We hypothesized that CM use in SM would affect the feeding behavior of calves during the weaning transition and in consequence, reduce their performance. The aim of this study was to determine the effect of $\mathrm{CM}$ and its inclusion rate in SM on frequency (no./d), time $(\mathrm{min} / \mathrm{d})$, and rate $(\mathrm{g} / \mathrm{min})$ of eating $\mathrm{SM}$ as well as frequency and time of drinking water during the weaning transition period.

Experimental procedures were reviewed and approved by the Local Ethical Committee (Krakow, Poland) before onset of the study. A total of 36 Holstein female calves with a mean age of $14.9 \pm 1.6 \mathrm{~d}$ and BW of 40.1 $\pm 4.2 \mathrm{~kg}$ (mean $\pm \mathrm{SD}$ ) were used for the study. Calves were collected from 3 dairy barns belonging to one operator Top Farms Głubczyce Sp. z o.o., Głubczyce, Poland), once per week (Monday), and transported 3 to $15 \mathrm{~km}$ to a naturally ventilated calf barn.

Before initiating the study, calves followed the routine procedure for newborn calves adopted at each farm. This included immediate separation from the dam and feeding $3 \mathrm{~L}$ of colostrum within the first $3 \mathrm{~h}$ of life.
Colostrum feeding was continued for the first $2 \mathrm{~d}$ of life, and thereafter transition milk was offered, followed by milk replacer (MR; Polmass Milk, Polmass S.A., Bydgoszcz, Poland) feeding beginning on d 5 of life. Liquid feeds were offered in an amount equal to $5 \mathrm{~L} / \mathrm{d}$. During that period of life calves were kept in individual hutches bedded with straw and no hay or SM was offered.

The required number of calves for the study was collected over a period of $4 \mathrm{wk}$, resulting in 4 blocks of 9 , 9,15 , and 3 calves. Upon arrival to the calf barn, calves were weighed, treated with a broad-spectrum antibiotic (Zactran, Merial, Lyon, France), placed in individual pens, and allocated to 1 of 3 experimental treatments (12 calves per treatment) differing in the main source of protein comprising the pelleted SM. Allocation to treatments accounted for place of birth (original farm) and initial BW. The treatments were (1) SBM as the main source of protein in the SM (TSBM); (2) SBM and CM as main sources of protein in the SM (TSBM/ TCM); and (3) CM as the main source of protein in the SM (TCM). Starter mixtures were formulated to be similar for CP content. For the TSBM/TCM, the same amount of $\mathrm{CP}$ was provided with SBM and CM. Because of lower content of $\mathrm{CP}$ in $\mathrm{CM}$, as compared with SBM, CM was included into SM in expense of barley grain. Detailed ingredient and chemical composition of SM is presented in Table 1.

Table 1. Ingredients and chemical composition (means \pm SD) of experimental feeds

\begin{tabular}{|c|c|c|c|c|}
\hline \multirow[b]{2}{*}{ Item } & \multicolumn{3}{|c|}{ Treatment $^{1}$} & \multirow{2}{*}{$\begin{array}{c}\text { Milk } \\
\text { replacer }\end{array}$} \\
\hline & TSBM & TSBM/TCM & TCM & \\
\hline \multicolumn{5}{|l|}{ Ingredient, $\%$ in feed } \\
\hline Soybean meal & 24.0 & 12.5 & - & \\
\hline Canola meal & - & 16.5 & 35.0 & \\
\hline Barley grain & 29.0 & 24.5 & 19.0 & \\
\hline Corn grain & 30.0 & 30.0 & 30.0 & \\
\hline Wheat bran & 6.0 & 6.0 & 6.0 & \\
\hline Glycerin & 3.0 & 3.0 & 3.0 & \\
\hline Whey & 2.5 & 2.5 & 2.5 & \\
\hline Molasses & 1.0 & 1.0 & 1.0 & \\
\hline Limestone & 2.0 & 2.0 & 2.0 & \\
\hline $\mathrm{NaCl}$ & 0.5 & 0.5 & 0.5 & \\
\hline Mineral-vitamin premix & 1.0 & 1.0 & 1.0 & \\
\hline Monocalcium phosphate & 1.0 & 0.5 & - & \\
\hline \multicolumn{5}{|l|}{ Chemical composition } \\
\hline DM, $\%$ & $90.2 \pm 0.5$ & $89.4 \pm 0.3$ & $88.9 \pm 0.6$ & $95.5 \pm 0.7$ \\
\hline $\mathrm{CP}, \%$ of $\mathrm{DM}$ & $23.0 \pm 0.4$ & $22.2 \pm 0.3$ & $21.8 \pm 0.3$ & $27.3 \pm 0.4$ \\
\hline Fat, $\%$ of DM & $1.7 \pm 0.3$ & $2.0 \pm 0.3$ & $2.7 \pm 0.3$ & $17.4 \pm 0.9$ \\
\hline Ash, \% of DM & $8.8 \pm 0.1$ & $8.6 \pm 0.3$ & $8.2 \pm 0.2$ & $8.9 \pm 0.1$ \\
\hline $\mathrm{NDF}, \%$ of DM & $13.5 \pm 1.2$ & $15.9 \pm 1.5$ & $18.2 \pm 0.9$ & - \\
\hline $\mathrm{ADF}, \%$ of $\mathrm{DM}$ & $6.0 \pm 0.1$ & $8.3 \pm 0.2$ & $11.0 \pm 0.3$ & - \\
\hline $\mathrm{Ca},{ }^{2} \%$ of DM & 1.06 & 1.07 & 1.10 & - \\
\hline $\mathrm{P}^{2} \%$ of $\mathrm{DM}$ & 0.68 & 0.68 & 0.69 & - \\
\hline
\end{tabular}

${ }^{1}$ TSBM $=$ soybean meal was used as the main source of protein in the starter mixture; TSBM/TCM $=$ soybean meal and canola meal were used as the main sources of protein in the starter mixture; TCM = canola meal was used as the main source of protein in the starter mixture.

${ }^{2}$ Calculated from NRC. 
Calves were fed $450 \mathrm{~g}$ of MR (as fed) twice a day $(0700$ and $1400 \mathrm{~h}$ ) from d 1 to 35 of the study and once a day $(0700 \mathrm{~h})$ from d 36 to 42 of the study, and were completely weaned on d 43 of the study $(57.9 \pm 1.6 \mathrm{~d}$ of age; mean $\pm \mathrm{SD}$ ). The MR (Polmass Milk, Polmass S.A.) was reconstituted at the rate of $150 \mathrm{~g}$ of MR powder in $1 \mathrm{~L}$ of water and offered from buckets in amount equal to $3 \mathrm{~L}$ per feeding. The SM was fed once a day (0900 h). Initially calves were offered $500 \mathrm{~g}$ of SM, and this amount was increased by an additional $500 \mathrm{~g}$ each time when less than $200 \mathrm{~g}$ of refusals remained. Milk replacer and SM intake was monitored daily. Calves were weighted weekly after the morning feeding $(1100 \mathrm{~h})$. Fecal fluidity (4-point scale: $1=$ normal; $4=$ diarrhea) was determined daily according to Larson et al. (1977), and every abnormal health condition and veterinary treatment was documented. Day with diarrhea was defined when fecal fluidity was $\leq 3$. During the whole study, calves were kept in $1.5 \times 1.2 \mathrm{~m}$ individual pens bedded with straw. Each calf was in the study for $56 \mathrm{~d}$.

Calves from the first and second block ( 6 calves per treatment) were continuously recorded during weaning transition on d 34 to 35 (before MR step-down), 41 to 42 (at MR step-down), and 48 to 49 (after weaning) of the study using a digital video recorder (model BCS-0404LE-AN, Dahua Technology Co., Hangzhou, China) equipped with 4 high-resolution color day/ night video cameras (EVA-TV-1200iRW, KAM-TECH, Krakow, Poland; angle lens 2.8-12 mm). Cameras were placed over pens ensuring that the bucket for feed and water for each calf was clearly visible on the video. One camera was used for recording 4 to 5 calves. Video recordings were saved on hard disk (resolution $720 \times 576$ pixels) with speed of 6 frames per second and watched by one person at the time of analysis. Frequency of eating SM and drinking water (no./d) and time of eating SM and drinking water $(\mathrm{min} / \mathrm{d})$ for each calf was recorded. Start of eating SM and drinking water was considered when calf put head into the bucked, and stop of eating SM and drinking water was considered when no interest with the bucked was observed for $10 \mathrm{~s}$. Feeding rate of SM $(\mathrm{g} / \mathrm{min})$ was calculated by dividing SM intake $(\mathrm{g} / \mathrm{d})$ by SM eating time $(\mathrm{min} / \mathrm{d})$.

Representative samples of feeds were collected weekly and composited by month of the study. Monthly samples were than analyzed for DM, ash, CP, and ether extract content using standard analytical procedures (procedures No. 934.01, 942.05, 976.05, 2003.05 for $\mathrm{DM}$, ash, CP, and ether extract, respectively; AOAC International, 2000), NDF (Van Soest et al., 1991), and ADL (Robertson and Van Soest, 1981).

Data were analyzed with a completely randomized block design using the MIXED procedure of SAS (ver.
9.2, SAS Institute Inc., Cary, NC). Effect of treatment was included in the statistical model as a fixed effect, whereas block was used as a random term. The statistical model for repeated variables included the effect of time (day or week) and the interaction between the effect of time and treatment as fixed effects (Littell et al., 1998). Optimal covariance structure (autoregressive order one, unstructured or compound symmetry) was chosen based on Akaike's criterion. For all analyzed parameters, initial age was used as a covariate. Preplanned contrasts were used for scientific hypothesis verification (TSBM vs. TSBM/TCM and TSBM vs. TCM). Significance was declared at $P \leq 0.05$ and tendencies at $P \leq 0.10$. Data are presented as least squares means and the corresponding standard error of the mean.

One calf was removed from statistical analysis because of extremely high SM intake and ADG and one because of extremely low ADG and poor health status, resulting in 12, 11, and 11 calves analyzed for TSBM, TSBM/TCM, and TCM, respectively. Although the $\mathrm{SM}$ were formulated to be similar for $\mathrm{CP}$ content, the SM offered to TSBM calves had slightly greater CP concentration as compared with the SM offered to TSBM/TCM and TCM calves (Table 1). Starter mixture offered to TSBM/TCM and TCM contained more NDF, ADF, and fat. The TCM calves had the least ADG from d 1 to 35 of the study $(P=0.02)$ and tended to have reduced ADG for the whole study $(P=0.08)$ as compared with TSBM calves (Table 2). Furthermore, TCM calves had the least feed efficiency, higher fecal fluidity, and greater number of days with diarrhea from d 1 to 35 of the study $(P \leq 0.03)$ as well as the least feed efficiency and greater number of days with diarrhea for whole study period $(P \leq 0.03)$ as compared with TSBM calves. The ADG and feed efficiency did not differ between TSBM and TSBM/TCM calves. From d 36 to 56 of the study, fecal fluidity was higher $(P=0.04)$ for TSBM calves as compared with TCM calves and tended to $(P=0.08)$ be higher for TSBM calves as compared with TSBM/TCM calves; however, number of days with diarrhea was not different. Treatments did not differ in SM intake with the exception of a tendency $(P=0.10)$ for higher SM intake from d 1 to 35 of the study for TSBM calves as compared with TSBM/TCM calves. Frequency, time, and rate of eating the SM increased during weaning transition $(P$ $<0.05$; Figure 1). Simultaneously, frequency and time of drinking water increased from the period before MR step-down to weaning $(P<0.05$; data not presented). No differences in feeding and drinking behavior were shown between treatments, with an exception for a tendency for more frequent water intake in TSBM calves 
Table 2. Least squares means for performance of calves fed starter mixtures differing in protein source

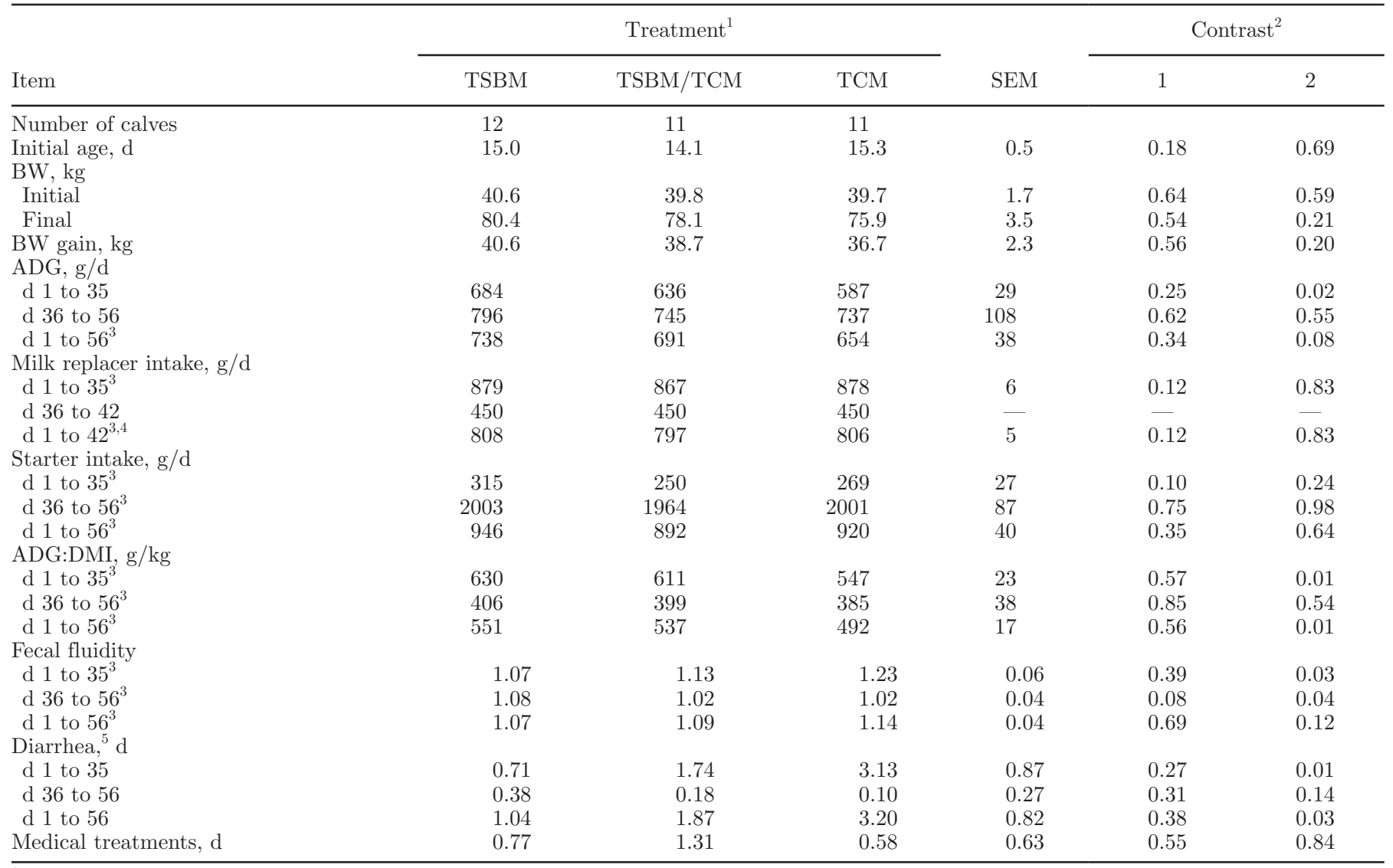

${ }^{1}$ TSBM $=$ soybean meal was used as the main source of protein in the starter mixture; TSBM/TCM = soybean meal and canola meal were used as the main sources of protein in the starter mixture; TCM = canola meal was used as the main source of protein in the starter mixture.

${ }^{2} 1=$ TSBM vs. TSBM/TCM; $2=$ TSBM vs. TCM.

${ }^{3}$ Significant effect of time $(P<0.01)$.

${ }^{4}$ Significant treatment $\times$ time interaction $(P<0.01)$.

${ }^{5}$ Fecal fluidity $\leq 3$ on a 4 -point scale.

as compared with TSBM/TCM calves $(P=0.10$; Table $3)$. However, it is worth noting that a tendency for a group $\times$ time interaction $(P=0.09)$ for SM eating time was observed, because of longer SM eating time on d 34 to 35 and shorter SM eating time on d 41 to 42 of the study for TSBM/TCM and TCM calves, as compared with TSBM calves.

This study confirmed a negative effect of CM use in SM on ADG and feed efficiency before weaning (Fiems et al., 1985; Khorasani et al., 1990), as well as showed

Table 3. Least squares means for behavior of calves fed starter mixtures differing in protein source

\begin{tabular}{|c|c|c|c|c|c|c|}
\hline \multirow[b]{2}{*}{ Item } & \multicolumn{3}{|c|}{ Treatment $^{1}$} & \multirow[b]{2}{*}{ SEM } & \multicolumn{2}{|c|}{ Contrast $^{2}$} \\
\hline & TSBM & TSBM/TCM & TCM & & 1 & 2 \\
\hline Starter intake, ${ }^{3} \mathrm{~min} / \mathrm{d}$ & 62.3 & 62.0 & 60.1 & 3.8 & 0.95 & 0.67 \\
\hline Starter intake rate, ${ }^{3^{\prime}} \mathrm{g} / \mathrm{min}$ & 20.6 & 24.8 & 24.6 & 2.3 & 0.24 & 0.23 \\
\hline Water intake, ${ }^{3}$ no. $/ \mathrm{d}$ & 12.9 & 15.7 & 14.7 & 1.1 & 0.10 & 0.25 \\
\hline
\end{tabular}

${ }^{1} \mathrm{TSBM}=$ soybean meal was used as the main source of protein in the starter mixture; TSBM/TCM = soybean meal and canola meal were used as the main sources of protein in the starter mixture; TCM = canola meal was used as the main source of protein in the starter mixture. ${ }^{2} 1=$ TSBM vs. TSBM $/ \mathrm{TCM} ; 2=\mathrm{TSBM}$ vs. TCM.

${ }^{3}$ Significant effect of time $(P<0.01)$. 

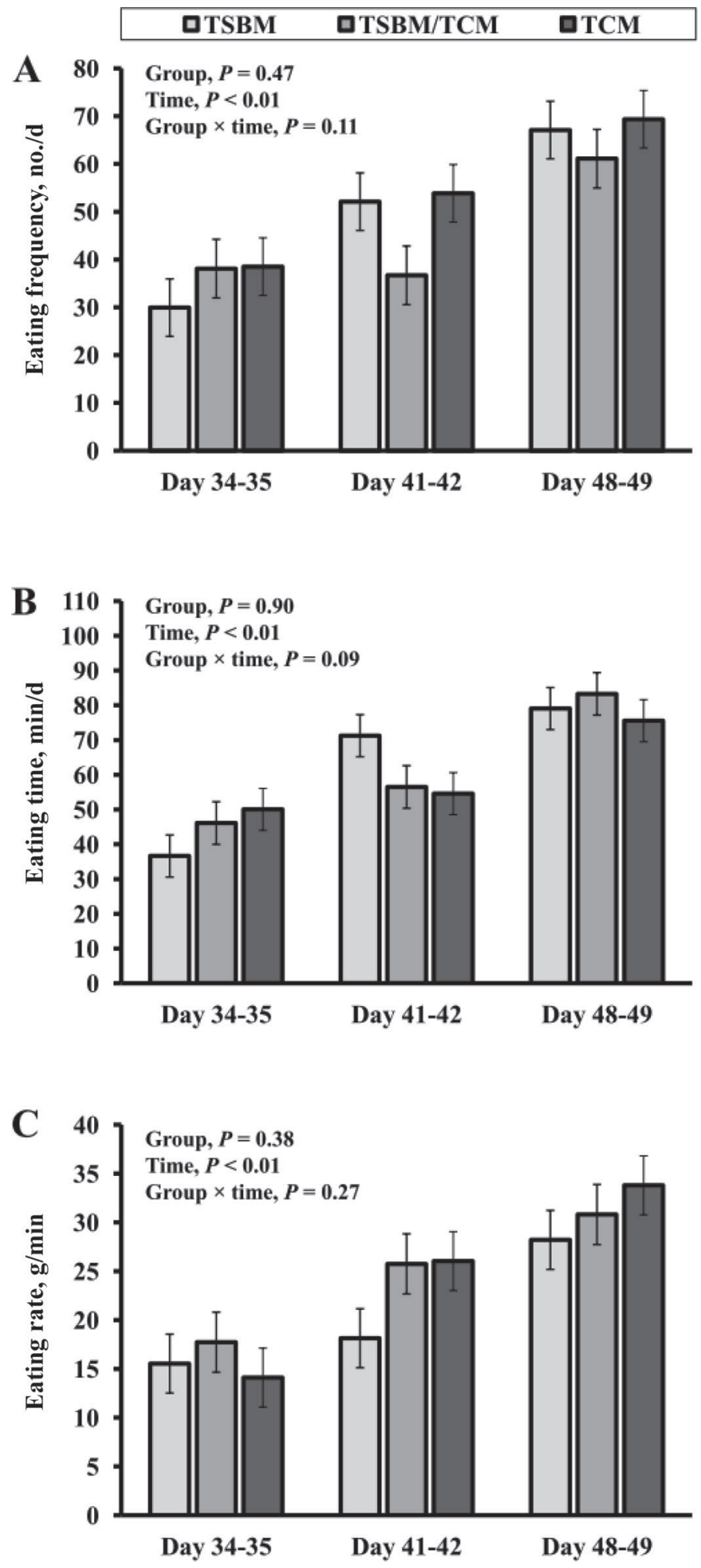

Figure 1. Effect of canola meal use as a protein source in starter mixture on starter mixture eating frequency $(\mathrm{A})$, time (B), and rate (C). TSBM = soybean meal was used as the main source of protein in the starter mixture; TSBM/TCM = soybean meal and canola meal were used as the main sources of protein in the starter mixture; TCM $=$ canola meal was used as the main source of protein in the starter mixture. Error bars indicate standard error of the mean. a negative effect of $\mathrm{CM}$ on health status of calves, as indicated by higher fecal score and greater number of days with diarrhea. However, several observations arising from this study are worth discussion. First, performance of calves was negatively affected by CM use in the SM from d 1 to 35 of the study, whereas no differences in ADG, feed efficiency, or health status of calves were observed from d 36 to 56, a period covering the weaning transition. Because relatively old calves were used for this study (14.9 $\pm 1.6 \mathrm{~d}$ of age), an even more pronounced negative effect of CM use in SM on performance of the youngest calves could have been expected, based on known high susceptibility of newborn calves to presence in the diet of some antinutritional factors (Drackley, 2008). Second, SM intake was not different between TSBM and TCM calves in this study, suggesting that low palatability of $\mathrm{CM}$ is not an important factor limiting efficiency of its use for newborn calves, as suggested by the results of other studies (Fiems et al., 1985). However, the SM used in this study contained glycerin and molasses that may help mask the sensory attributes of CM. Third, up to $50 \%$ replacement of SBM with CM in SM had no negative effect on ADG of calves, feed efficiency, and number of days with diarrhea in this study, indicating that partial replacement of SBM with CM in SM for calves may be acceptable in practical conditions.

Because even small changes in chemical composition of the diet may affect feeding behavior of cattle (Taylor and Allen, 2005), and this may itself affect the rumen environment and feed efficiency (Allen, 1997), we hypothesized that a negative effect of $\mathrm{CM}$ on the performance of calves may be at least partially a result of its effect on feeding behavior. This hypothesis is also supported by low palatability of CM (Fiems et al., 1985; Khorasani et al., 1990), which may have a substantial effect on feeding behavior of calves. Furthermore, because SM intake increases rapidly at weaning (Quigley et al., 2006; Laarman et al., 2012), the effect of CM use in a SM on the feeding behavior and performance of calves could be especially apparent during weaning transition. Results of this study did not confirm our hypothesis, although a tendency for a group $\times$ time interaction $(P=0.09)$ for SM eating time was observed, as a result of longer SM eating time on d 34 to 35 and shorter SM eating time on d 41 to 42 of study for TSBM/TCM and TCM calves, as compared with TSBM calves. However, feeding behavior was not analyzed during first 4 wk of the study (d 1 to 28); the time point where a negative effect of CM use in the SM on performance of calves was especially apparent. Nevertheless, SM intake in first $4 \mathrm{wk}$ of the study was low $(\approx 200 \mathrm{~g} / \mathrm{d})$, and thus, it can be speculated that the potential effect of CM on feeding behavior of calves that 
occurred during that period of study, if it occurred, was rather of minor importance for feed efficiency.

We conclude that the inclusion of CM in a SM does not affect feeding behavior and performance of calves during the weaning transition. However, CM inclusion as a full replacement for SBM in SM has a negative effect on ADG, feed efficiency, and fecal score of calves during the preweaning period.

\section{ACKNOWLEDGMENTS}

This study was funded by the Ministry of Science and Higher Education of Poland (BM-4233/KŻZiP/2013). The authors acknowledge the Top Farms Głubczyce (Głubczyce, Poland) staff for help in collecting data.

\section{REFERENCES}

Allen, M. S. 1997. Relationship between fermentation acid production in the rumen and the requirement for physically effective fiber. J. Dairy Sci. 80:1447-1462.

AOAC International. 2000. Official Method of Analysis. 17th ed. AOAC Int., Washington DC.

Claypool, D. W., C. H. Hoffman, J. E. Oldfield, and H. P. Adams, 1985. Canola-meal, cottonseed, and soybean meals as protein supplements for calves. J. Dairy Sci. 68:67-70.

DeVries, T. J., and E. Chevaux. 2014. Modification of the feeding behavior of dairy cows through live yeast supplementation. J. Dairy Sci. 97:6499-6510.

Drackley, J. K. 2008. Calf nutrition form birth to breeding. Vet. Clin. North Am. Food Anim. Pract. 24:55-86.
Fiems, L. O., V. Boucque, B. G. Cottyn, and X. F. Bysse. 1985. Evaluation of rapeseed meal with low and high glucosinolates as a protein source in calf starters. Livest. Prod. Sci. 12:131-143.

Fisher, L. J. 1980. A comparison of rapeseed meal and soybean-meal as a source of protein and protected lipid as a source of supplemental energy for calf starter diets. Can. J. Anim. Sci. 60:359-366.

Khorasani, G. R., W. C. Sauer, L. Ozimek, and J. J. Kennelly. 1990 Digestion of soybean meal and canola meal protein and amino acids in the digestive tract of young ruminants. J. Anim. Sci. 68:3421-3428.

Laarman, A. H., T. Sugino, and M. Oba. 2012. Effects of starch content of calf starter on growth and rumen $\mathrm{pH}$ in Holstein calves during the weaning transition. J. Dairy Sci. 95:4478-4487.

Larson, L. L., F. G. Owen, J. L. Albright, R. D. Appleman, R. C. Lamb, and L. D. Muller. 1977. Guidelines toward more uniformity in measuring and reporting calf experimental data. J. Dairy Sci. 60:989-991.

Littell, R. C., P. R. Henry, and C. B. Ammerman. 1998. Statistical analysis of repeated measures data using SAS procedures. J. Anim. Sci. 76:1216-1231.

Lunn, D. E., T. Mutsvangwa, N. E. Odongo, T. F. Duffield, R. Bagg, P. Dick, G. Vessie, and B. W. McBride. 2005. Effect of monensin on meal frequency during sub-acute ruminal acidosis in dairy cows. Can. J. Anim. Sci. 85:247-249.

Quigley, J. D., T. A. Wolfe, and T. H. Elsasser. 2006. Effects of additional milk replacer feeding on calf health, growth, and selected blood metabolites in calves. J. Dairy Sci. 89:207-216.

Robertson, J. B., and P. Van Soest. 1981. Chapter 9: The detergent system of analysis. Pages 123-158 in The Analysis of Dietary Fiber in Food. W. P. T. James and O. Theander, ed. Marcel Dekker, New York, NY.

Taylor, C. C., and M. S. Allen. 2005. Corn grain endosperm type and brown midrib 3 corn silage: Feeding behavior and milk yield of lactating cows. J. Dairy Sci. 88:1425-1433.

Van Soest, P. J., J. B. Robertson, and B. A. Lewis. 1991. Methods for dietary fiber, neutral detergent fiber, and nonstarch polysaccharides in relation to animal nutrition. J. Dairy Sci. 74:3583-3597. 